International Journal of Economics, Business and Accounting Research (IJEBAR)

Peer Reviewed - International Journal

Vol-4, Issue-2, 2020 (IJEBAR)

E-ISSN: 2614-1280 P-ISSN 2622-4771

https://jurnal.stie-aas.ac.id/index.php/IJEBAR

\title{
THE EFFECT OF BUREAUCRATIC REFORM TO THE QUALITY OF PUBLIC SERVICES IN THE POPULATION AND CIVIL REGISTRATION OF SIKKA DISTRICT
}

\author{
Yoseph Darius Purnama Rangga1, Antonius Philipus Kurniawan Gheta2 \\ 1,2Lecture in Faculty Ekonomi of Nusa Nipa University Maumere, Flores Island \\ E-mail:jo.darius1206@gmail.com
}

\begin{abstract}
This study aims to determine whether bureaucratic reform has an influence on the quality of public services in the Population and Civil Registry Office of SIKKA Regency. This research is a descriptive study with a quantitative approach. The sample in this study amounted to 33 people consisting of 4 officials including the head of the Office and 29 employees who work in the Office of Population and Civil Registry of Sikka Regency. The data collection techniques in this study used interview techniques, questionnaires and documentation. The results of this study indicate that the bureaucratic reform variable influences the quality of public services in the Office of Population and Civil Registry of Sikka Regency by $32.8 \%$.
\end{abstract}

Keywords: $\quad$ bureaucratic reform, quality of public services

\section{Introduction}

Public service is one of the important tasks that cannot be ignored by the local government because if the service component occurs stagnation it is almost certain that all sectors will have a traffic jam. For this reason, there needs to be good planning and even the formulation of service standards for the community in accordance with the authority given by the central government to the regional government, where the implementation of the regional government is directed to accelerate the realization of community welfare through service improvement, empowerment, and community participation, as well as regional competitiveness by paying attention to the principles of democracy, government, justice, and the power of a region in the unitary system of the Republic of Indonesia.

Therefore, Indonesian Bureaucracy Reform has always been a public opinion that is never boring, this is because until now the bureaucracy in Indonesia is still problematic and far from what was expected. Bureaucracy which is not ideal is one of the problems in Indonesia. Complaints about the low performance of public services and the lack of quality apparatus resources such as never ending, and cannot yet find effective solutions to overcome them.

The Sikka Regency's Office of Population and Civil Registration seeks to implement governance with principles of good governance, transparency, accountability and accountability to Accountability, which is an important aspect that needs attention and is implemented in government management. Performance Accountability at least contains a vision, mission, goals and targets that have clear directions and benchmarks for the strategic planning formulation of the Population and Civil Registry Office as a description of the results to be achieved in the form of measurable, testable and reliable targets.

2017 is the fourth year in an effort to achieve the goals and objectives of the Sikka Regency RPJMD 2013 - 2018. In general, the achievement of targets through target indicators shows 
success in efforts to realize the mission and objectives as stated in the Regional Regulation of Sikka District Number 1 of 2014 concerning Development Plans Medium-Term Sikka Regency Year 2013 - 2018 and Decree of the Head of the Population and Civil Registry Office of Sikka Regency Number 06 Year 2016 regarding Key Performance Indicators and has been stated in the Performance Agreement (PK) of the Sikka Regency Population and Civil Registry Office in 2017 which is a full commitment Head of Service to carry out optimal performance as part of efforts to fulfill official missions.

\section{Literature Review}

\section{Bureaucratic Reform}

Related to the government's efforts to improve the bureaucracy, which can eventually be called bureaucratic reform. Then there are various definitions of bureaucratic reform, with different notions of bureaucratic reform. According to the MenPan (www.menpan.go.id, accessed August $19,2014)$, bureaucratic reform is an attempt to make fundamental reforms and changes to the system of governance, especially concerning aspects of the application of excellent service. According to the Directorate General of Laws and Regulations (www.djenjen kemenkumham.go.id, accessed August 20, 2014), said that bureaucratic reform is an effort to change, where changes are made related to bureaucratic reform, namely: Changes in ways of thinking, Structuring of legislation , Strengthening the organization, structuring governance, apparatus HR Management, Strengthening supervision, Strengthening performance accountability, and Improving the quality of public services.

\section{Quality of Public Services}

Quality of public services according to Pasolong (2008: 210), as follows: "Quality is basically a word that bears relative meaning because it is abstract, quality can be used to assess or determine the degree of adjustment of a matter to its requirements or specifications. If the requirements or specifications are met, it means that the quality of something that is meant can be said well, conversely if the requirements are not met then it can be said to be not good. Thus, to determine the quality of service, an indicator is needed.

\section{Organization of Public Services}

The organizer of this public service activity is a government agency. According to Moenir, U.S (2008: 186), elements of public service cannot be separated from one another because the four service elements will form a process of activity (activity), including:

1. Service duties

In general services, the government must provide services in accordance with the duties received to serve all the interests of the community.

2. Service system or procedure

In public services there needs to be an information system, procedures and methods that support the smooth delivery of services.

3. Service activities

In public services activities aimed at the community must be able to meet needs without discrimination.

4. Service providers

The government as the service provider as much as possible regulates and plans the program carefully so that the service process will produce a service structure that is easy, fast, straightforward and easily understood by the public. 


\section{Research Method}

\section{Population and Sample}

The population in this study consisted of 4 officials including the head of the Dinas and 29 employees working in the Sikka Regency's Office of Population and Civil Registration. Quoting from the opinion of Arikunto (1996: 104) which states that if the population is less than 100 people, the sample is taken from the whole, while the population is above 100 people, then the sample is taken $10 \%, 15 \%$ or $20 \%-25 \%$ of the population. Because the population in this study is less than 100, the sample is the entire population of 33 people.

\section{Types and Data Sources}

\section{Data Type}

According to Indrianto and Supomo (2002: 145), research data are grouped into three, namely:

a. Subject data (selft - report data)

Is the type of research data in the form of opinions, attitudes, experiences or characteristics of a person or group of people who are the subject of research (respondents).

b. Physical data

Is a type of research data in the form of objects or physical objects, including in forms; buildings or parts of buildings, clothing, books and others. Physical data is tangible objects that are evidence of an existence or event in the past, physical data in business research is collected through observation methods.

c. Documentary data (documentary data)

Documentary data is a type of research data in the form of: invoices, journals, letters, minutes of meetings, memos or in the form of program reports. Documentary data includes what and when an event or transaction, and who was involved in an event.

In this study, the type of data used is a combination of subject data, physical data and documentary data. Asking the respondent directly is subject data, buildings and infrastructure are physical data while LAKIP, employee data and appropriate journals are documentary data types.

\section{Data Source}

According to Sugiyono (2010: 225), data sources used in research data collection are:

\section{Primary Data Sources}

Namely the data source that directly provides data to data collectors. The primary data in this study are the results of interviews in accordance with the questionnaire obtained directly from the people who received administrative services at the Office of Population of Sikka Regency.

2. Secondary Data Sources

Namely the source of data that does not directly provide data to data collection. Secondary data in this study is evidence, notes or reports arranged in an archive.

\section{Operational Definition and Research Variables}

According to Sugiyono (2010: 156), the definition of Operations is the definition given to a variable by giving meaning or specifying an activity or providing an operation needed to measure the variable.

\section{Bureaucratic reform}

Bureaucratic reform (administration) is an attempt to change the government in the system of government administration to create or make conditions better than before by involving bureaucracy as a target of change so that the bureaucracy becomes more qualified.

2. Quality of public services

The government's effort to create satisfaction for service users is satisfied with the service, if the service user feels satisfied with the service received, it can be concluded that the government has 
provided services that are in accordance with the government's duties. (Goetsch and Davis, 2001; 101).

\section{Data Analysis Technique}

Ghozali (2005 : 129), data analysis is to estimate or to determine the magnitude of the quantitative influence of one (some) events on a (some) other events, as well as predict / predict other events. An event can be expressed as a change in the value of a variable. The data analysis process begins with a review of all data obtained through both the results of the questionnaire and interview assistance. The purpose of the data analysis method is to interpret and draw conclusions from a number of collected data. Quantitative Analysis is a data analysis method that requires statistical and mathematical calculations. To simplify the analysis, SPSS version 20 is used.

\section{Results and Discussion}

\section{Validity Test}

The bureaucratic reform variable consists of 10 statement items and the public service quality variable consists of 10 statement items. The validity test results using the SPSS.20 program, the results shown in table 1 below:

Table 1 Validity Test Results

\begin{tabular}{|c|c|c|c|c|}
\hline \multirow{2}{*}{$\begin{array}{l}\text { No } \\
\text { Item }\end{array}$} & \multicolumn{2}{|c|}{ Correlation Coefficient } & \multirow{2}{*}{$\begin{array}{c}\text { Validity Test } \\
\text { Criteria }\end{array}$} & Remarks \\
\cline { 2 - 3 } & $\begin{array}{c}\text { Bureaucratic } \\
\text { Reform }\end{array}$ & $\begin{array}{c}\text { Service Quality } \\
\text { of Public }\end{array}$ & 0.30 & Validity \\
\hline 1 & 0.622 & 0.677 & 0.30 & Validity \\
\hline 2 & 0.831 & 0.659 & 0.30 & Validity \\
\hline 3 & 0.810 & 0.332 & 0.30 & Validity \\
\hline 4 & 0.833 & 0.660 & 0.30 & Validity \\
\hline 5 & 0.763 & 0.514 & 0.30 & Validity \\
\hline 6 & 0.793 & 0.630 & 0.30 & Validity \\
\hline 7 & 0.326 & 0.561 & 0.30 & Validity \\
\hline 8 & 0.529 & 0.594 & 0.30 & Validity \\
\hline 9 & 0.515 & 0.535 & 0.30 & Validity \\
\hline 10 & 0.505 & 0.340 & \multicolumn{3}{c}{} \\
\hline
\end{tabular}

(Source: SPSS. 20)

Based on table 1 above, it can be seen that the results of the validity test analysis show that all statement items for bureaucratic reform variables and the quality of public services have a correlation coefficient value greater than 0.3 so that it is declared valid. Thus, the statements submitted in this research questionnaire can be used to measure the research variables.

\section{Reliability Test}

The bureaucratic reform variable consists of 10 statement items and the public service quality variable consists of 10 statement items. The reliability test results using the SPSS.20 program, obtained the results shown in table 2 below:

Table 2 Reliability Test Results

\begin{tabular}{|c|c|c|c|c|c|c|c|}
\hline \multicolumn{3}{|c|}{ Bureaucratic Reform } & \multicolumn{4}{c|}{ Service Quality of Public } \\
\hline $\begin{array}{c}\text { No } \\
\text { Ite }\end{array}$ & $\begin{array}{c}\text { Cronb } \\
\text { ach's }\end{array}$ & $\begin{array}{c}\text { Cronb } \\
\text { ach's }\end{array}$ & Remarks & $\begin{array}{c}\text { No } \\
\text { Ite }\end{array}$ & $\begin{array}{c}\text { Cronbac } \\
\text { h's alpha }\end{array}$ & $\begin{array}{c}\text { Cronbach' } \\
\text { s alpha if }\end{array}$ & Remarks \\
\hline
\end{tabular}




\begin{tabular}{|c|c|c|c|c|c|c|c|}
\hline $\mathrm{m}$ & alpha & $\begin{array}{l}\text { alpha } \\
\text { if item } \\
\text { deleted }\end{array}$ & & $\mathbf{m}$ & & $\begin{array}{c}\text { item } \\
\text { deleted }\end{array}$ & \\
\hline 1 & \multirow{10}{*}{0.859} & 0.853 & Reliability & 1 & \multirow{10}{*}{0.722} & 0.675 & Reliability \\
\hline 2 & & 0.827 & Reliability & 2 & & 0.681 & Reliability \\
\hline 3 & & 0.830 & Reliability & 3 & & 0.720 & Reliability \\
\hline 4 & & 0.828 & Reliability & 4 & & 0.679 & Reliability \\
\hline 5 & & 0.836 & Reliability & 5 & & 0.701 & Reliability \\
\hline 6 & & 0.832 & Reliability & 6 & & 0.690 & Reliability \\
\hline 7 & & 0.866 & Reliability & 7 & & 0.694 & Reliability \\
\hline 8 & & 0.857 & Reliability & 8 & & 0.691 & Reliability \\
\hline 9 & & 0.860 & Reliability & 9 & & 0.735 & Reliability \\
\hline 10 & & 0.861 & Reliability & 10 & & 0.735 & Reliability \\
\hline
\end{tabular}

(Source: SPSS. 20)

The results of the reliability test of bureaucratic reform variables and the quality of public services in table 2 show that the value of Cronbach's alpha exceeds the minimum requirements of 0.6. Thus it can be said that all the questionnaires from these two variables are reliable so that they can be used for further data analysis.

\section{Simple Regression Analysis}

The results of a simple linear regression analysis using the SPSS.20 program, the results can be seen in the following table:

Table 3 Analysis of Coefficientsa Regression

\begin{tabular}{|c|c|c|c|c|c|c|}
\hline \multirow{2}{*}{\multicolumn{2}{|c|}{ Model }} & \multicolumn{2}{|c|}{$\begin{array}{c}\text { Unstandardized } \\
\text { Coefficients } \\
\end{array}$} & \multirow{2}{*}{$\begin{array}{c}\begin{array}{c}\text { Standardized } \\
\text { Coefficients }\end{array} \\
\text { Beta }\end{array}$} & \multirow[b]{2}{*}{$\mathrm{t}$} & \multirow[b]{2}{*}{ Sig. } \\
\hline & & B & Std. Error & & & \\
\hline 1 & (Constant) & 20.694 & 3.180 & & 6.508 & \\
\hline & $X$ & .353 & .091 & .573 & 3.892 & \\
\hline
\end{tabular}

a. Dependent Variable: Y

(Source: Data Analysis Results, SPSS. 20)

Based on the results of the data analysis in table 3 above, the following simple linear regression equation model is determined as follows:

$\mathrm{Y}=20,694+0.353 \mathrm{X}$

Based on the regression equation above, it can be explained for constants and the regression coefficients can be described as follows:

1. Constants (bo): 20,694

The constant value for the regression equation is 20,694 with positive parameters. This means that without a bureaucratic reform variable (X), the quality of public services (Y) is already 20,694

2. Regression coefficient X (b): 0.353

The value of the regression coefficient for the variable $(\mathrm{X})$ is 0.353 with positive parameters. This regression coefficient can be explained that if there is an increase in the bureaucratic reform variable $(\mathrm{X})$ by one unit, it will result in an increase in the variable quality of public service (Y) by 0.353 units. 


\section{Hypothesis Test}

Hypothesis testing is done by $t$ test using the SPSS program. 20. Based on the data analysis in table 4.6, the steps to test the hypothesis ( $\mathrm{t}$ test) are as follows:

\section{Hypothesis}

Ho: $\mathrm{b} 1=0$, meaning that bureaucratic reform $(\mathrm{X})$ has no significant effect on the quality of public services (Y)

Ha: $\mathrm{b} 1 \neq 0$, meaning that bureaucratic reform $(\mathrm{X})$ has a significant effect on the quality of public services $(\mathrm{Y})$

2. Determine the level of significant

In this study the level of significant $\alpha=0.05$ is used. with a level of significant $\alpha=0.05$ obtained $\mathrm{t}$ table as follows:

ttable $1=\alpha / 2: \mathrm{n}-\mathrm{k}$

$=0.05 / 2 ; 33-2$

$=0.025 ; 31$

$=2.03$

3. Testing criteria

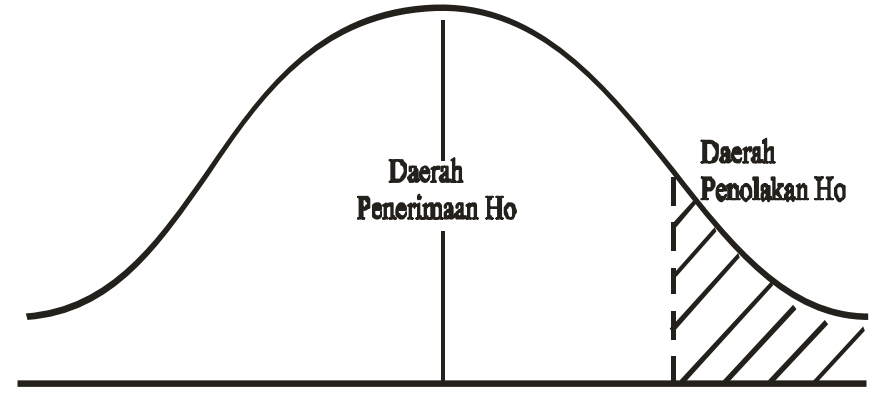

$-2.032 .03$

Figure Distribution Curves t

Ho is accepted if:

$-2.03 \leq \mathrm{t}$ count $\leq 2.03$

Ho is rejected if: $t$ count $>2.03$ or $t$ count $<-2.03$

4. Calculation results

The results of calculations according to table 4.6 obtained t count for the bureaucratic reform variable $(\mathrm{X})$ of 3,892

5. Conclusions

Based on the calculation results for the bureaucratic reform variable $(\mathrm{X})$, the $\mathrm{t}$ count value of $3,892>2.03$ is obtained, so ho is rejected, meaning that bureaucratic reform is significant on the quality of public services (Y).

In addition to the above calculations, the $t$ test can also be done by looking at the significance value. Based on table 4.6, the significant value for the bureaucracy reform variable (X) is 0,000 . This significance value is smaller than the alpha level used 5\% (0.05), the decision is to accept an alternative hypothesis (Ha) and reject the null hypothesis (Ho), thus the bureaucratic reform variable $(\mathrm{X})$ has a positive and significant effect on the variable quality of public service (Y). If the bureaucratic reform variable is getting better, the variable quality of public services will also be better.

\section{Determination Analysis}


The results of the analysis using the SPSS.20 program obtained R2 results can be seen in the following table:

Tabel 3 Coefficient Determinasi Model Summary

\begin{tabular}{|l|l|r|c|c|}
\hline Model & $\mathrm{R}$ & R Square & $\begin{array}{c}\text { Adjusted R } \\
\text { Square }\end{array}$ & $\begin{array}{c}\text { Std. Error of the } \\
\text { Estimate }\end{array}$ \\
\hline 1 & $.573 \mathrm{a}$ & .328 & .307 & 2.92470 \\
\hline
\end{tabular}

a. Predictors: (Constant), $\mathrm{X}$

(Source: Data Analysis Results)

Based on the results of data analysis in table 4.8 above, it can be seen that the coefficient of determination (R2) is 0.573 , which means the contribution of bureaucratic reform variable $(\mathrm{X})$ to the quality of public services (Y) in the Office of Population and Civil Registry of Sikka Regency is $32.8 \%$ while the remaining $67.2 \%$ is explained by other variables not included in this research model.

\section{Conclusion and Suggestions}

\subsection{Conclusion}

Based on the results of the analysis discussed, the conclusions of the results of this study are as follows:

a. Respondent's perception value for bureaucratic reform variable is 69,15 . Based on the percentage achievement of the maximum score it can be concluded that this variable is included in the category of "Good Enough". The results of this descriptive analysis show that the bureaucratic reform variable needs to be improved so that it can reach the excellent and very good categories. that the respondent's perception value for the variable Public Service Quality (Y) is 65.81. The variable perception of Public Service Quality (Y) consists of 10 statements with the highest value Safe from danger, risk or doubt and the lowest value is the consistency of performance and the ability to be trusted. Based on the percentage achievement of the maximum score it can be concluded that the patient satisfaction variable is included in the "good enough" category. The results of this descriptive analysis indicate that the variable Quality of Public Services (Y) needs to be improved so that it can reach both good and very good categories.

b. The coefficient of determination (R2) of 0.573 , which means the contribution of the bureaucratic reform variable $(\mathrm{X})$ to the quality of public services $(\mathrm{Y})$ in the Office of Population and Civil Registry of Sikka Regency is $32.8 \%$ while the remaining $67.2 \%$ is explained by other variables not included in this research model. The conclusion contains a brief summary of the results of research and discussion. It is recommended to load the novelty of the research results. Suggestions can be included in this section

\subsection{Suggestions}

In connection with the discussion and conclusions above, the author will also provide some suggestions that are expected to provide benefits to the Office of Population and Civil Registry of Sikka Regency in order to improve the quality of public services. As for these suggestions, namely:

a. The implementation of bureaucratic reform is monitored as an institution to ensure that all stages are passed well, targets are achieved according to plan, and deviations are immediately identified and can be corrected. 
b. Bureaucratic reform is carried out in accordance with statutory regulations.

c. Bureaucratic reform is carried out consistently from time to time, and covers all levels of government, including individual employees.

d. Bureaucratic reform must provide broad space for ministries / institutions and local governments to innovate in the administration of government, exchange of knowledge, best practices to produce better performance.

e. For future research, it is suggested to add other independent variables besides bureaucratic reform which certainly can influence the dependent variable of public service quality so that it can be more complementary from this research, because there are still other independent variables outside of this research that might be influential or influences the quality of public services in Sikka Regency's Office of Population and Civil Registration.

\section{References}

Arikunto, 1996, prosedur penelitian, Rineka Cipta, Jakarta.

Goetsch, David. L, Staanley B.Davis, 2001, Quality Management, Introduction to Total Quality Management for Production, processing, and services, New Jersey: Prentice Hall.

Ghozali, Imam. 2005. Aplikasi Analisis Multivariate dengan SPSS. Semarang: Badan Penerbit UNDIP.

Moenir, H.AS, 2008. Manajemen Pelayanan Umum Di Indonesia, Bumi Aksara. Jakarta

Pasolong, Harbani.2008. Teori Administrasi Publik,Alfabeta, Bandung.

Supomo dan Indriantoro, 2002, Metodologi Penelitian Bisnis, Cetakan Kedua, Yogyakara; Penerbit BFEE UGM.

Sugiyono, 2010. Metode Penelitian Pendidikan Pendekatan Kuantitatif, kualitatif, dan R\&D.

www.menpan.go.id

www.djenjen kemenkumham.go.id 